\title{
Spectacles of Piety: Prayer and the Politics of Mass Arousal in Democratic Nigeria
}

\author{
Ebenezer Obadare
}

\section{Preamble: Praying against enemies of state in Ekiti}

In December 2015, a few days before the Christmas holidays, Governor Peter Ayodele Fayose of Ekiti State hosted a prayer session on the grounds of the state's government house. It was a difficult time in Ekiti, consistently ranked by commentators as one of Nigeria's most politically turbulent states. It was also Fayose's second tenure as governor. He took the reins from Dr. Kayode Fayemi in May 2015 after decrying the latter's purported elitism and promising the state's civil servants a return to the ostensibly happy era of his first tenure from May 2003 to October 2006 when, he boasted, salaries were paid as and when due.

But December 2015 saw Fayose clearly struggling to deliver on his campaign promises. For instance, by the time he convened the prayer session in question, civil servants in the state had not been paid their salaries for three months. It was not entirely the governor's fault, of course. As the global price of oil cascaded, Nigeria, reliant on oil revenue to a sickening degree, was taking in considerably less cash, which meant that the federal government's capacity to disburse funds to the state was hampered, which also meant that the state of Ekiti had no "allocation" from which it could discharge its own obligations. Ekiti's situation was therefore not unlike that of other states across the country, and what the

\footnotetext{
An earlier version of this chapter was presented as part of an invited panel on "Anthropology of the Crowd: The I, the We, the US" at the American Anthropological Association (AAA) Annual Conference, Washington, DC, December 2014. Financial support for research that the paper draws on was provided by the New Directions in the Study of Prayer (NDSP) program of the Social Science Research Council (SSRC), New York, and the University of Kansas General Research Fund (GRF). I thank Megan Steffen for her close reading and helpful comments. I am grateful to Taline Cox, Wei Zhu, Candace West, Nancy Myers, Whitney Onasch, Janelle Williams, and Corinne Butler for sundry logistical support. For, among other things, her generosity with her time and ideas, this paper is gratefully dedicated to Joane Nagel.
} 
governor did-paying the workers a percentage of their basic pay as "Christmas bonus"-was in fact what majority of the cash-strapped state governors had done. Still, critics of the state governor charged that the convocation of a special prayer session within the premises of the government house at that point in time was nothing but a ruse by the governor to distract attention from the state's economic problems, particularly the state's inability to pay its workers' salaries.

Whether the critics were right or not, a mere look at the cross section of dignitaries at the special prayer session suffices to confirm that the governor intended at least to have many of the state's most prominent citizens at his side. Among those in attendance were the state's deputy governor, Dr. Kolapo Olusola; the First Lady, Mrs. Feyisetan Fayose; the wife of the deputy governor, Mrs. Janet Olusola; Secretary to the State Government, Dr. Mrs. Modupe Alade; Chief of Staff to the governor, Barrister Dipo Anisulowo; and Special Adviser to the governor on political matters, Alhaji Ademola Bello. But this being no ordinary prayer session, there were also in attendance high-ranking naval officers, all suited up in their official navy uniforms, police officers, a cross section of some of the leading clerics in the state, several prominent politicians, and ordinary citizens.

The capstone of the event was the special prayer for the state and against its "enemies." Given the situation in the state, there were only a few surprised glances when a clearly emotional Governor Fayose, clad in all white buba and sokoto, went down on his knees in the middle of the yard, his right hand clenched, the left holding on tightly to the voice microphone. This was his favored "prayer warrior" pose, and as he inveighed against the state's "detractors" and invited "God's judgment" on them, the crowd, numbering in hundreds, followed his cue. There was a collective charge even as individual supplicants embraced their idiosyncratic poses-some stamped on the ground insistently, some raised both hands, a few (like the governor) sank to their knees, while others spoke passionately in tongues. In short order, a strident clamor of supplication tore the solemn air of the government house premises.

Spectacles like this have become very common since Nigeria returned to civil rule in May 1999, a period that coincided with the explosion of Pentecostal Christianity in the country. One legitimate way to view such spectacles is as ordinary proof of the manner in which Pentecostal forms have become rapidly insinuated into official ceremonies all over the country. For instance, the modality of the Ekiti special prayer session-its orgiastic emotionality and sensationality-is a recognized fixture of African Pentecostal devotional performance. So, also, is the event itself: the resort to prayer emerging here as an expression of Pentecostal belief in the power and efficacy of prayer. 
What do these religious ceremonies-which I describe in this chapter as spectacles of piety - typically convoked at the instance of leading public officials, signify? How do such ceremonies advance our understanding of what I call religious politicality, meaning the ways in which those occupying formal political office manipulate religious symbols and performances for political purposes? What insights into the religiopolitical economy do they afford? Who is the audience for these spectacles? What implied and unwitting ideological effects do these spectacles have on that audience? Finally, what can we learn from these spectacles about crowds and about this animated but ultimately rather peaceable crowd in particular? In what follows, I will try to pursue these questions, using the Ekiti prayer session as my immediate empirical material, but also, where necessary, drawing on similar examples from contemporary Nigeria.

\section{Contending trajectories}

These spectacles are undeniably freighted with political and symbolic meaning. For instance, the image of "a whole governor" (as the Nigerian expression goes) kneeling down in public can be seen as a demonstration of calculated humility, ostentatiously staged to curry acceptance in a social context in which humility, especially by highly placed public officials and the "powerful" in general, is seen as a virtue. In going down on his knees, Governor Fayose was merely following the path of ostentatious humility well trodden by other state dignitaries, most notably former president Goodluck Jonathan, who, on at least two occasions in 2012 and 2015 respectively, publicly knelt down for prayers before the General Overseer of the Redeemed Christian Church of God (RCCG), Pastor Enoch Adejare Adeboye. It goes without saying that insofar as ostentatious humility ${ }^{1}$ what Jean-Pascal Daloz (2006) describes as "conspicuous modesty" - is inspired by the performer's need for acceptance by the public; it must be linked to their designs on political survival. For instance, President Jonathan's diligent, if unpolished, courting of Pastor Adeboye, and indeed the cream of the Pentecostal elite throughout his tenure, has to be seen as part of his determination to leverage the latter's enhanced social status and control over large congregations.

No less analytically fruitful is the space in which these spectacles are hosted, considering that it is almost impossible to contemplate global Pentecostalism as an "aesthetic experience" (Largier 2009) or indeed its entire presentation as a "sensorium" (Meyer 2012) without thinking about space. Olufunke Adeboye's work on the conversion of cinema halls in urban centers across Nigeria into 
spaces of worship highlights "how Pentecostals ventured out of conventional church halls into general open grounds, and their appropriation of spaces hitherto demonized as 'abode(s) of sin for worship"' (2012: 146). For her, "Pentecostals need to register their presence publicly and symbolically possess such public sites for Christ as a way of publicly asserting their identity" (156). While I think she is correct, it is equally plausible that common logistics and economic calculations (the crowd for the average open-air crusade is usually tremendous, often numbering in the hundreds of thousands) rather than a simple desire to sanctify or "symbolically possess" account for the fact that an increasing number of Pentecostal mega events tend to take place in "demonized spaces" like sport stadia.

At any rate, given the symbolic interest in sanctification, the hosting of a blatantly Pentecostal ceremony within the premises of a government house must feel like mission accomplished for Pentecostals who believe that the physical space of the government house is in fact one in special need of cleansing. This belief is intelligible in a cultural paradigm in which not only are power and politicians seen as innately amoral, government houses in particular are associated in the public mind with shady deals, oaths, cultic ceremonies, and all sorts of dark rituals. In addition, a Pentecostal ceremony convened by the symbolic "father of the state" himself must be especially gratifying for Pentecostals, who may rightly point to the governor as a unique "capture," a "symbolic possession" no longer available to both the denominational and nondenominational competition.

When spectacles of piety are convoked elsewhere-in a stadium, say-the associations can be more poignant, perhaps because the visual backdrop is usually strikingly different. No matter the dark monsters supposedly lurking in state houses and government offices, at least they (the state houses, not the monsters) are easy on the (naked, not spiritual) eye, what with their carefully manicured lawns, freshly painted walls, and an unmistakable air of wealth and good living. One can hardly say the same about most soccer stadia in Nigeria, many of which, in their gross dereliction and utter neglect, afford a different sort of testimony to the failings of Nigerian politics and politicians. For example, on February 15, 2013, Emmanuel Uduaghan, governor of Delta State at the time, convened and led a two-day "prayer retreat" at the Stephen Keshi stadium in Asaba, the state capital. An estimated 30,000 citizens of the state filled the stadium for an event that promised the "Power to Recover All." Unwittingly, photographs of the event tell the story of an uncompleted stadium, the victim of a contract wrangling. The governor did not miss the opportunity to ask for prayer against "the spiritual inhibition stalling the progress of the project." 
Nevertheless, whether held in a swanky official residence or a dilapidated stadium, such prayer sessions are wonderful avenues for an elaboration of what Ash Amin and Nigel Thrift in their work on the affective machinery describe as "affective proximity" or "momentary neural binding" between state officials and the electorate $(2013: 15,168)$. This happens as, even if only for a fleeting moment, both the governor and the governed occupy the same physical space, join hands in prayer, press flesh, and find temporary unity in a "relation of conviviality" (Mbembe 1992: 24). Yet, even as voices are raised in prayer, furtive glances and complimentary cards are exchanged between social agents eager to "connect," placing such events firmly within the currents of Nigeria's omnipresent patronclient networks. ${ }^{2}$

As an instance of what David Morgan (2011) has described as a "community of feeling," these spectacles provide evolving illustrations of how the political shades into the religious and vice versa and how the notionally "political" or "religious" are dynamically constituted. The political nature of these events is unquestionable. But what is even more fascinating within that political context is the variety of specific political uses to which, depending on personal taste and social circumstance, various public officials put these events. For instance, Udom Emmanuel, the governor of Akwa Ibom State, chose the June 2016 monthly prayer meeting to announce both the conclusion of plans to dissolve the state's Local Government Transition Committee and news that three new refineries in the state would soon begin operation. By collapsing any assumed distinctions between the religious pulpit and the official platform, Governor Emmanuel guides us into the unstable conglomeration that is the evolving agency of the state governor: part public official, part social engineer, part moral guardian, part theologian.

\section{A note on context}

A better appreciation of these public prayers might be gained by situating them within the evolving theologico-political milieu of Africa. Scattered references have been made supra, but I make the following two observations as a way of further underscoring the context. The first observation is to note the emergent social ecology that has seen Pentecostalism make significant inroads into power and the social imaginary across the continent and particularly in countries like Nigeria, Ghana, Zimbabwe, Ghana, and increasingly, South Africa. Amid what seems like a "democratization of charisma" (Asamoah-Gyadu 2004), not only 
do state and society continually crisscross but also the religious idiom is allencompassing, which reinforces the accepted wisdom of the literature on the conjoining of the scared and the profane. More to the point, such is the power of the emergent religious public that, for political leaders and other secular authorities, an open declaration of religious allegiance or, more specifically in certain social contexts, an ostentatious affirmation and performance of one's "born-again" status is fashionable, which confirms Pentecostalism's emerging status as "a prestige good" (Daloz 2006).

The second, and closely related, observation is that the emerging identity and popularity of prayer is perhaps the most compelling element within the nascent religious formation in Africa. In David Maxwell's study of the Pentecostal movement in Zimbabwe, prayer is an inalienable element in the transformation of Pentecostals into a community of believers and the means through which "their struggle for betterment is acted out" (2006: 197). Other studies have addressed prayer as "a means of reconstructing nationalism as a spiritual obligation" (Oha 2005); ritual prayer as a means through which Pentecostalism creates modern consumers (Lindhardt 2009a); prayer as a tool of deliverance from "occult forces" (Lindhardt 2009b); and prayer as an instrument of democratic mobilization by a resurgent civil society (Obadare 2012). In a recent study (Obadare 2016), I have formulated prayer as the centerpiece in a new organization of devotion by Christian and Islamic groups and as an interesting sign of convergence in the "dialogic constitution" of Christianity and Islam (Larkin 2008, 103; cf. Hirschkind 2006; and Mahmood 2005). In this latter regard, prayer practices, forms, and performances are sites for the staging of interfaith struggles and at the same time conduits for the incorporation of exogenous forms and modalities. In this chapter, a specific form of public prayer-what I've been calling spectacles of piety-is analyzed as an aspect of the complex political repertory of political elites in Nigeria.

\section{The argument}

We owe the resurgence of interest in religious crowds partly to growing scholarly interest in Pentecostal megachurches (see, for instance, Stevenson 2013). Birgit Meyer's work in this regard focuses on their affective dimension, particularly the "kinds of religious sensations, in the sense of feelings ... generated when religions adopt new sensational forms such as the spectacle" (2008: 713). 
This chapter draws attention to an important but largely neglected political dimension of such gatherings. To do that, I note the specific pedigree of the public prayer sessions in question here as ecumenical (by invocation, if not in practice) spectacles "ordered" by important public officials. ${ }^{3}$ This sets them apart from conventional religious gatherings organized by particular religious denominations. Paradoxically, however, it makes them sociological cousins of other state-directed crowdsourcing activities directly targeted at the "manufacturing" of civic solidarity. A good example is the series of one-millionman marches organized to drum up support for the ultimately abortive efforts of the late Nigerian military despot, Sani Abacha (1993--1998), to transform into a civilian president (Obadare 2005).

My three main arguments flow directly from this initial postulation of such spectacles as politically laden events as follows:

I argue, first, that these events constitute rituals of demobilization propelled by the desire to create "an obsequious flock" (Canetti 1984). This can happen through the performance of what I have already described as ostentatious humility. The claim here is that insofar as it entails a politician actually repudiating the very basis of his authority (as seen for example in various "humble" admissions that only God can actually do what they were statutorily elected to do, in short by confessing to incapacity), ostentatious humility becomes effectively a project of avoidance, the staging of a ruse that subtly extends the ideology of the state, disguises its impunities, and hence furthers its legitimation. Furthermore, the cause of demobilization may be advanced through constructed transparency, as when a public official puts before a sympathetic crowd "all the facts" of a controversial subject as a way of preempting public discussion of them and legitimating the official position on them. This was arguably the case with Governor Uduaghan of Delta state (discussed above) in the matter of the uncompleted Stephen Keshi stadium. In the end, the governor succeeded in selling the idea that delay over the completion of the project had nothing to do with financial mismanagement, as his critics alleged, but with an unspecified "spiritual inhibition."

Second, I argue that spectacles of piety have a target audience by which I mean that they are ideological "plays" intended for a clear group of "consumers." That audience may include not only the immediate participants but also, and perhaps more importantly, distant observers who are invited to behold the piety and humility of the governor. In actual fact, one may rightly surmise that it is this combined piety and humility that is on "display" in such spectacles. In this 
way, the staging of public prayer falls within the complex described by Peter Sloterdijk (2013) as the "psychotechnics" of power.

Third, because spectacles of piety are ideological "plays," they are political scripts staged in anticipation of definite ideological effects, with the most desired effect being the production of manipulable political subjects. They are, therefore, technologies of governance, similar to other activities political leaders engage in (like starting a foreign war) with the aim of distracting the public.

\section{Crowds: Between irrationality and pose}

The argument staked out thus far on the uses of spectacles of piety for political manipulation would seem to place me firmly within the camp of authors who have taken a rather dim view of the crowd and mass audiences in general. For such authors, what stands out about the crowd-and indeed its distinguishing psychological attribute-is its irrationality and suggestibility. The pioneering work in this regard is the French sociologist Gustave Le Bon's The Crowd: A Study of the Popular Mind, originally published in 1896. For Le Bon, something happens when an ordinary-and ordinarily rational-individual becomes part of a crowd:

By the mere fact that he forms part of an organized crowd, a man descends several rungs in the ladder of civilization. Isolated, he may be a cultivated individual; in a crowd, he is a barbarian - that is, a creature acting by instinct. He possesses the spontaneity, the violence, the ferocity, and also the enthusiasm and heroism of primitive beings, whom he further tends to resemble by the facility with which he allows himself to be impressed by words and images-which would be entirely without action on each of the isolated individuals composing the crowdand to be induced to commit acts contrary to his most obvious interests and his best-known habits. An individual in a crowd is a grain of sand amid other grains of sand, which the wind stirs up at will. (2002: 8)

Le Bon's view of the crowd as "irrational," "conservative," even "dictatorial," was apparently justified by events in pre-Second World War Europe where German Nazism and Italian fascism caught fire amid delirious crowds. The sight may have informed the English writer and philosopher Aldous Huxley's Le Bonesque view of crowds as a herd (cf. Ward 1924), an irrational lump susceptible to the whims of malevolent authority. Wrote Huxley: 
When crowd-delirium is exploited for the benefit of governments and orthodox churches, the exploiters are always very careful not to allow the intoxication to go too far. The ruling minorities make use of their subjects' craving for downward self-transcendence in order, first, to amuse and distract them and, second, to get them into a sub-personal state of heightened suggestibility. Religious and political ceremonials are welcomed by the masses as opportunities for getting drunk on herd-poison, and by their rulers as opportunities for planting suggestions in minds which have momentarily ceased to be capable of reason or free will. (Huxley 1952: 319)

Le Bon's and, ipso facto, Huxley's approach to understanding crowds and crowd psychology has been criticized by other scholars, notably Rudé (2005), who followed very closely in the footsteps of Georges Lefebvre (1934), in particular the latter's eagerness to draw "a sharp distinction between 'crowd' as an involuntary social gathering, e.g. people queueing for food or talking after church, and 'assembly' as a more deliberate voluntary association, e.g. political meeting" (Holton 1978, 220). Nonetheless, skepticism about the agency of crowds and specifically their presumed susceptibility to "political seduction" has continued to echo in work that addresses democratic populism (see, for instance, Vincent 2011; cf. Furedi 1973).

A rejection of the presumed innate savagery of the crowd and a more positive appraisal of its radical potential seems to be the guiding motif of recent critique of neoliberal hegemony. The key work in this regard is Multitude: War and Democracy in the Age of Empire (2004) by philosophers Michael Hardt and Antonio Negri. Working in the same register, Mazzarella pursues "the social potential of group energies that relies neither on the fortress of the autonomous liberal subject (crowd theory) nor on a principled but critically disabling attachment to immanent, unmediated potentiality (multitude theory)" (2010: 698). And, as it turns out, AbdouMaliq Simone's analysis of "people as infrastructure" in urban South Africa (2004) is in part, if not indeed, an invitation and a philosophical nudge toward a sympathetic understanding of massed bodies.

A similar rejection of a simplified understanding of the crowd as an irrational horde seems to undergird Achille Mbembe's (1992) notion of "intimate tyranny." Mbembe appears interested less in affirming the reasonableness of "ordinary people" in Africa than in underscoring how complex their social and political practices are. He begins by acknowledging that "people are always trapped in a net or rituals that affirm tyranny, and secondly, these rituals however minor are intimate in nature" $(1992,22)$. However, this loop of tyranny is never closed 
because "ensnarement" is always counterbalanced and undermined by "evasion" or "avoidance." As a result, what he refers to as "the simulacrum" is in fact

the dominant modality of transactions between the state and society, or between the rulers and those who are supposed to obey. This is what makes postcolonial relations relations of conviviality, but also of powerlessness par excellence-from the point of view either of the masters of power or of those whom they crush.

(Mbembe 1992: 24, italics in original)

Taken with the ethnographic encounters described above, we are led to the conclusion that such occasions are a "dance" in which all participants, from the state governors through the religious clerics and the military officers to the ordinary citizens, are cognizant of their "roles." Such a conclusion is not unreasonable. After all, the way in which such events are also an occasion or opportunity for political networking has been acknowledged. However, Mbembe's point actually precedes that, as he seems to be suggesting (at least in my reading), ultimately, participation in these spectacles cannot result in a net loss for ordinary people who are merely feigning docility as part of the smokesand-mirrors economy of "the simulacrum." On this view, not only is the crowd aware of its being manipulated, it is also simultaneously carrying on its own manipulating.

Now, there is great value in not seeing ordinary people as effete subjects totally lacking in agency or invention. But we should be anxious about the analytic and philosophical implications of a social flattening in which there are no winners and losers - such a flattening means that the real consequences and intentions of elite repertoires and technologies to deflect dissent are overlooked. The overriding aim in this chapter is to show how religious belief and feelings can be mobilized to deflect attention, create a discursive smokescreen, and eventually mold a specific kind of political subjectivity.

\section{Conclusion}

Because crowds are protean phenomena with heterogeneous pedigrees and constantly changing forms and behaviors, it is difficult to speak of a "typical" crowd. Not only are no two crowds ever the same, as a matter of fact the same crowd, altering in nature and form, may exhibit contrasting features in the course of its evolution within a period of time. This is why, historically, crowds have been a moving target, analytically speaking. We see confirmation of this 
inherent fluidity in the examples referenced here-all unquestionably political, yet deployed in alliance with various local political permutations.

Nevertheless, and as already shown, we can identify certain commonalities that speak to their coherence as carefully staged spectacles of piety. To this end, these spectacles afford us some tentative and rather limited insights into the construction of a narrow category of religious crowds. As already emphasized, the backdrop to these, and arguably the social register within which such spectacles are elaborated, is the explosion of Pentecostalism as a denominational force. Kramer's work in a Latin American context (2005) and Texas Governor Rick Perry's 2011 "Days of Prayer for Rain in the State of Texas" show that the Nigerian scenarios are hardly unique, that Pentecostalism is no stranger to this sort of "staging of power," and that some of the conclusions from Nigeria may well find resonance in seemingly alien regional and cultural contexts. 